\title{
Inhibition of pituitary-gonadal axis in mice by long-term administration of D-Trp-6-LHRH microcapsules*
}

\author{
L. Bokser†, A. Zalatnai† and A. V. Schally $\dagger \ddagger$ \\ $\uparrow$ Section of Experimental Medicine, Department of Medicine, Tulane University School of \\ Medicine, 1430 Tulane Avenue, New Orleans, LA 70112, USA; and $\$$ Endocrine, Polypeptide and \\ Cancer Institute, Veterans Administration Medical Center, 1601 Perdido Street, New Orleans, \\ $L A 70146, U S A$
}

\begin{abstract}
Summary. Female mice were injected, every 30 days for 5 months, with a long-acting formulation of microcapsules liberating $2.5 \mu \mathrm{g}$ D-Trp-6-LHRH/day. The control group was injected with vehicle only. At 30 days after the last injection mice were killed, ovaries, uteri and adrenals were weighed and fixed in formalin for histological studies. LH and oestradiol concentrations were measured by RIA. In the D-Trp-6-LHRHtreated group, the weights of the ovaries and uterus $(P<0.01$ and $P<0.05$, respectively), and $\mathrm{LH}$ and oestradiol values $(P<0.02$ and $P<0.01$, respectively) were reduced compared to controls. Histologically, the ovaries contained a large number of degenerated, atretic follicles, and corpora lutea had almost completely disappeared. These results indicate, contrary to the prevailing opinion, that mice are sensitive to inhibitory effects of LHRH agonists and that a suppression of the pituitary-gonadal axis can be obtained with long-term administration of D-Trp-6-LHRH microcapsules.
\end{abstract}

Keywords: LHRH agonist; mouse; microcapsules; ovary; LH; oestradiol

\section{Introduction}

Chronic administration of superactive agonists of luteinizing hormone-releasing hormone (LHRH), such as D-Trp-6-LHRH, produces a marked inhibitory effect through 'down regulation' of receptors and desensitization of pituitary gonadotrophs (Schally et al., 1980; Schally \& Coy, 1983). This inhibition of the pituitary-gonadal axis is manifested by a decrease in the secretion of LH, FSH and gonadal steroids. These antifertility effects have been observed in rats (Johnson $e t$ al., 1976; Auclair et al., 1977; Sandow et al., 1978; Hsueh \& Erickson, 1979; Maynard \& Nicholson, 1979; Schally et al., 1980; Schally \& Coy, 1983), and primates including humans (Corbin et al., 1978; Bergquist et al., 1979; Linde et al., 1981; Tolis et al., 1981), but not mice, which is thought to be the only animal species resistant to the paradoxical inhibitory effect of LHRH agonists (Bex et al., 1982; Wang et al., 1983).

We have developed a long-acting delivery formulation of D-Trp-6-LHRH microcapsules which releases therapeutic concentrations of the analogue for 30 days or longer after intramuscular injection (Mason-Garcia et al., 1985). The efficacy of this continuous delivery system in the treatment of sex hormone-dependent tumours has been demonstrated in laboratory animals (Redding et al., 1984; Mortel et al., 1986; Schally et al., 1986) and in man (Parmar et al., 1985; Roger et al., 1985; Kullander et al., 1987; Mathé et al., 1987).

\footnotetext{
*Reprint requests to: Dr Andrew V. Schally, Endocrine, Polypeptide and Cancer Institute, Veterans Administration Medical Center, 1601 Perdido Street, New Orleans, LA 70146, USA.
} 
Since the continuous release formulations of LHRH agonists are much more efficacious than daily injections, the aim of this study was to evaluate the effect of long-term administration of D-Trp-6-LHRH microcapsules on the pituitary-gonadal axis in mice.

\section{Materials and Methods}

Adult female Swiss CD-1 mice (Charles River), maintained on a $12 \mathrm{~h}$ light (06:00-18:00 $\mathrm{h}$ ): $12 \mathrm{~h}$ dark schedule, were injected subcutaneously every 30 days for 5 months with microcapsules of D-Trp-6-LHRH (Group T), which consisted of D-Trp-6-LHRH ( $2 \%, w / w)$ distributed within a polymeric matrix of poly (DL-lactide-co-glycolide) $(98 \%$, $\mathrm{w} / \mathrm{w})$. The microcapsules, in $3 \mathrm{mg}$ portions calculated to release about $2.5 \mu \mathrm{g}$ per day for 30 days, were suspended in disposable syringes in $0.5 \mathrm{ml}$ of injection vehicle consisting of $0.2 \% \mathrm{CM}$-cellulose and $1 \%$ Tween 20 in water (Redding et al., 1984; Mason-Garcia et al., 1985; Schally et al., 1986). The suspension was mixed thoroughly on a Vortex mixer and injected subcutaneously through an 18-gauge needle. Control mice (Group C) were injected only with the vehicle. Mice were killed 30 days after the last injection. Ovaries, uteri and adrenals were weighed and blood samples were taken from the abdominal aorta for measurement of LH and oestradiol concentrations. LH was determined by specific radioimmunoassay (RIA) using materials supplied by the National Hormone and Pituitary Program (NHPP) (Niswender et al., 1968). Oestradiol was extracted from the serum and measured using a kit provided by Radioassay System Laboratories, Inc. (Carson, CA, USA) (Abraham, 1974). The removed organs were fixed in $8 \%$ buffered formalin and embedded in Paraplast, and serial sections of $6 \mu \mathrm{m}$ were cut. The diameters of the follicles were measured by using a net micrometer disc on haematoxylin and eosin-stained sections. Primordial follicles were not counted. The statistical significance was assessed by Student's $t$ test.

\section{Results}

After 5 months of treatment, Group T mice showed a decrease in the weight of ovaries $(P<0.01)$, and uteri $(P<0.05)$ (Table 1) compared to controls. Serum LH and oestradiol concentrations were also significantly reduced in the mice in Group T $(P<0.02$ and $P<0.01$, respectively). Body weight increased in Group $\mathrm{T}(P<0.01)$, but there was no difference in the weight of adrenals between the groups (Table 1).

Table 1. Body, ovarian, uterine and adrenal weights and serum LH and oestradiol concentrations in control mice (Group C) and mice treated with microcapsules of D-Trp-6-LHRH (Group T), administered every 30 days for 5 months at a dose liberating $2.5 \mu \mathrm{g}$ D-Trp-6-LHRH/day

\begin{tabular}{lcccccc}
\hline & $\begin{array}{c}\text { Body } \\
\text { weight } \\
(\mathrm{g})\end{array}$ & $\begin{array}{c}\text { Ovarian } \\
\text { weight } \\
(\mathrm{mg})\end{array}$ & $\begin{array}{c}\text { Uterus } \\
\text { weight } \\
(\mathrm{mg})\end{array}$ & $\begin{array}{c}\text { Adrenal } \\
\text { weight } \\
(\mathrm{mg})\end{array}$ & $\begin{array}{c}\text { LH conc. } \\
(\mathrm{ng} / \mathrm{ml})\end{array}$ & $\begin{array}{c}\text { Oestradiol } \\
\text { conc. } \\
(\mathrm{pg} / \mathrm{ml})\end{array}$ \\
\hline $\begin{array}{l}\text { Group C } \\
(\mathrm{N}=7)\end{array}$ & $40 \cdot 8 \pm 1 \cdot 2$ & $38 \cdot 1 \pm 2 \cdot 6$ & $160 \cdot 1 \pm 16 \cdot 7$ & $7 \cdot 8 \pm 0 \cdot 9$ & $0 \cdot 580 \pm 0 \cdot 126$ & $25 \cdot 2 \pm 2 \cdot 1$ \\
$\begin{array}{l}\text { Group T } \\
(\mathrm{N}=10)\end{array}$ & $46 \cdot 6 \pm 1 \cdot 1^{* * *}$ & $12 \cdot 1 \pm 1 \cdot 6^{* * *}$ & $105 \cdot 6 \pm 14 \cdot 5^{* *}$ & $7 \cdot 3 \pm 1 \cdot 0$ & $0 \cdot 188 \pm 0 \cdot 050^{*}$ & $15 \cdot 0 \pm 0 \cdot 6^{* * *}$ \\
\hline
\end{tabular}

Values are mean \pm s.e.m.

${ }^{*} P<0.05 ;{ }^{* *} P<0.02 ;{ }^{* * *} P<0.01$ compared with control.

In the ovaries of Group $C$ animals, the corpora lutea $(19 \cdot 8 \pm 2 \cdot 5)$ proved to be the predominating elements (Fig. 1), while in Group $T$ their number was markedly reduced $(1.5 \pm 0 \cdot 7: P<0.001)$. More than half of the specimens contained no corpora lutea at all, and in the remaining animals their number was between 1 and 4 . The interstitial and hilus cells were hyperplastic. There were no significant differences in the number $(4 \cdot 2 \pm 2.5$ and $6.2 \pm 1 \cdot 8)$ and diameter $(208 \pm 26.2 \mu \mathrm{m}$ and $228 \pm 24.8 \mu \mathrm{m}$ ) of the follicles between Group C and T, respectively. However, most of the follicles showed signs of degeneration, and a great number of atretic follicles appeared (Fig. 2). Two cases 


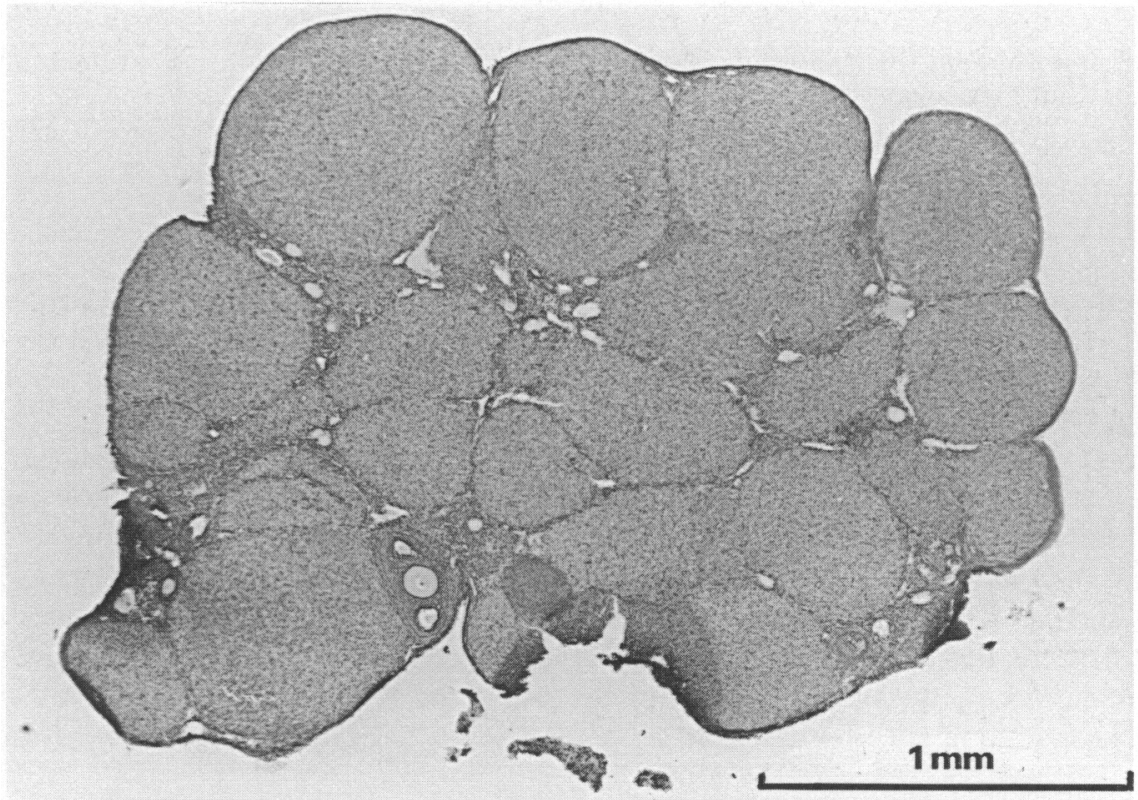

Fig. 1. Histological section of the ovary from Group $C$ mouse. There are large numbers of corpora lutea. $\mathrm{H} \& \mathrm{E}, \times 40$.

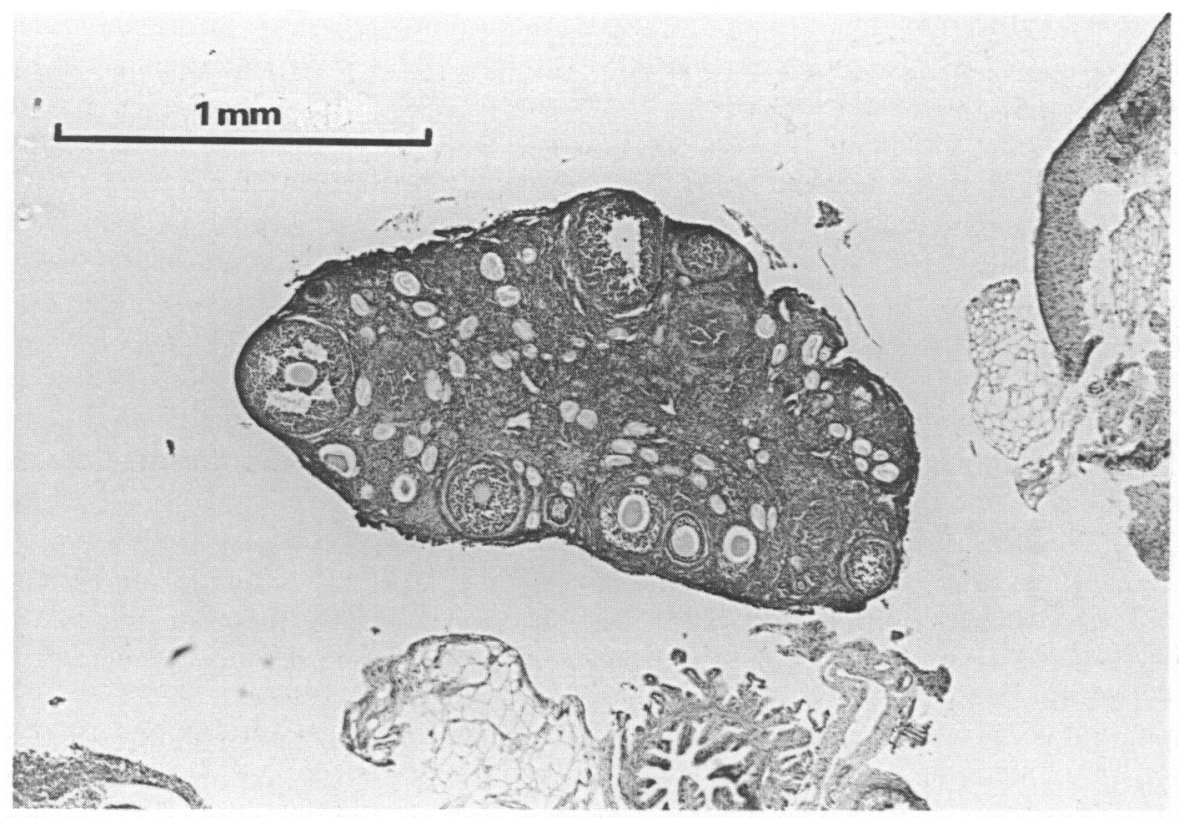

Fig. 2. The ovary from a D-Trp-6-LHRH-treated mouse is atrophic, the follicles show degeneration and many are atretic. Note the absence of corpora lutea. H\&E, $\times 40$. 
of endometrial hyperplasia were seen in Group T mice: the glands were lined by stratified columnar epithelium, and some of them showed cystic dilatation. No secretion was found in the lumina. The adrenals showed no microscopic alterations.

\section{Discussion}

Although the mouse responds well to the stimulatory action of LHRH and its agonistic analogues, as indicated by elevation of serum LH (Banik \& Givner, 1977), it is reputed to be resistant to the antifertility effects of agonistic analogues of LHRH (Bex et al., 1982; Wang et al., 1983). Doses of LHRH agonists, that were 8000 times greater per unit body weight than those used in rats, induced only partial inhibition or no inhibition of the pituitary-gonadal axis in mice (Bex et al., 1982). However, in our previous studies we repeatedly noted inhibitory effects of D-Trp-6-LHRH in BDF1 mice implanted with oestrogen-dependent MXT mammary tumours, as shown by the reduction in ovarian weights, decrease in progesterone concentrations, and suppression of tumour growth (Redding \& Schally, 1983). A similar gonadal inhibition was recorded after treatment with $\mathrm{D}$-Trp-6-LHRH in male or female mice bearing other transplanted tumour models. A significant suppression of the growth of ovarian carcinoma (OVCAR 3) was also obtained in nude mice by administration of D-Trp-6-LHRH microcapsules (Mortel et al., 1986).

In the present experiment, we injected D-Trp-6-LHRH microcapsules into female mice for 5 months. In previous studies (Redding et al., 1984; Mason-Garcia et al., 1985; Schally et al., 1986) we demonstrated that adult rats injected with $30 \mathrm{mg}$ portions of microcapsules which release about $25 \mu \mathrm{g}$ D-Trp-6-LHRH per day showed analogue levels in the range of $500-1000 \mathrm{pg} / \mathrm{ml}$ for more than 30 days. In this work, it was estimated that doses of microcapsules injected into mice should have produced similar levels of D-Trp-6-LHRH. At the conclusion of treatment the analoguetreated mice showed a significant decrease in ovarian and uterine weights, as well as reduction in serum LH and oestradiol concentrations, as compared to controls. The histological changes in the ovaries correspond to these findings and indicate a monophasic low-level hormonal status. In the D-Trp-6-LHRH treated group, 2 uteri showed endometrial cystic hyperplasia which, in human pathology, is regularly seen associated with anovulatory cycles (Ramzy, 1983). These results indicate, contrary to the prevailing opinion, that female mice are sensitive to inhibitory effects of LHRH agonists, and that a marked suppression of the pituitary-gonadal axis can be obtained by long-term continuous administration of D-Trp-6-LHRH using delayed delivery microcapsules. However, the sensitivity of the pituitary-gonadal axis of mice to inhibitory effects of LHRH agonists is less than in other species, as indicated by previous reports (Bex et al., 1982), and longer treatment and larger doses than those used in rats (Schally et al., 1986) are necessary to achieve inhibition of the gonadal axis. With larger doses of microcapsules, liberating $12.5 \mu \mathrm{g}$ D-Trp-6$\mathrm{LHRH} /$ day, inhibition of the pituitary-gonadal axis in $\mathrm{Nu} / \mathrm{Nu}$ nude mice can be obtained within 1 month (T. W. Redding \& A. V. Schally, unpublished). The gonadal suppression obtained in mice in this study could be due to the great efficacy of the continuous release microcapsule formulation of our agonist (Redding et al., 1984; Schally et al., 1986). The microcapsules are normally injected intramuscularly, even in rats, but in mice and hamsters it is necessary to administer them subcutaneously. Microcapsules of D-Trp-6-LHRH have been successfully used for the treatment of hormone-dependent tumours in humans (Parmar et al., 1986; Kullander et al., 1987; Mathé et al., 1987).

Nude mice are very useful for the study of transplanted human cancers. Since mice show an inhibition of the pituitary-gonadal axis in response to the delayed release formulation of D-Trp-6LHRH, our study indicates that nude mice with xenografts of human neoplasms can be used as experimental animals for studying the effect of LHRH agonists on prostate, breast, ovarian and other hormone-dependent or endocrine-sensitive cancers. 
We thank the National Hormone and Pituitary Program (NHPP) for the gift of materials used in radioimmunoassays and Miss Martha Sampson and Dr F. Del Toro for their valuable experimental assistance. The work described in this paper was supported by the National Institute of Health Grants DK 07467, CA 40003, and CA 40004 (to A.V.S.) and by the Medical Research Service of the Veterans Administration.

\section{References}

Abraham, G.E. (1974) Radioimmunoassay of steroids in biological fluids. Clin. Biochem. 71, 193-201.

Auclair, C., Kelly, P.A., Labrie, F., Coy, D.H. \& Schally, A.V. (1977) Inhibition of testicular luteinizing hormone receptor level by treatment with a potent luteinizing-hormone releasing hormone agonist or human chorionic gonadotropin. Biochem. Biophys. Res. Commun. 75, 855-862.

Banik, U.K. \& Givner, M.L. (1977) Comparative ovulation inducing capacity of a synthetic luteinizing hormone-releasing hormone and two analogs in adult rats and mice. Fert. Steril. 28, 1243-1249.

Bergquist, C., Nillius, S.J. \& Wide, L. (1979) Intranasal gonadotrophin-releasing hormone agonist as a contraceptive agent. Lancet ii, 215-216.

Bex, F.J., Corbin, A. \& France, E. (1982) Resistance of the mouse to the antifertility effects of LHRH agonists. Life Sci. 30, 1263-1269.

Corbin A., Beattie, C.W., Tracy, J., Jones, R., Foell, T.J., Yardley, J. \& Rees, R.W.A. (1978) The anti-reproductive pharmacology of LH-RH and antagonistic analogues. Int. J. Fertil. 23, 81-92.

Hsueh, A.J.W. \& Erickson, G.F. (1979) Extra-pituitary inhibition of testicular function by luteinizing hormone-releasing hormone. Nature, Lond. 281, 66-67.

Johnson, B., Gendrich, R.L. \& White, W.F. (1976) Delay of puberty and inhibition of reproduction processes in the rat by a gonadotrophin hormone-releasing hormone agonist. Fert. Steril. 27, 853-860.

Kullander, S., Rausing, A. \& Schally, A.V. (1987) LH-RH agonist treatment in ovarian cancer. In Hormonal Manipulation of Cancer: Peptides, Growth Factors, and New (Anti) Steroidal Agents, pp. 315-319. Eds J. G. M. Klijn, R. Paridaens \& J. Foekens. Raven Press, New York.

Linde, R., Doelle, G.C., Alexander, N., Kirchner, F., Vale, W., Rivier, J. \& Rabin, D. (1981) Reversible inhibition of testicular steroidogenesis and spermatogenesis by a potent gonadotropin-releasing hormone agonist in normal men. N. Engl. J. Med. 305, $663-667$.

Mason-Garcia, M., Vigh, S., Comaru-Schally, A.M., Redding, T.W., Somogyvari-Vigh, A., Horvath, J. \& Schally, A.V. (1985) Radioimmunoassay for 6-DTryptophan analog of luteinizing hormone-releasing hormone: measurement of serum levels after longacting microcapsule formulation. Proc. natn. Acad. Sci. USA 82, 1547-1551.

Mathé, G., Keilling, R., Prevot, G., Vovan, M.L., Gastiaburu, J., Vannetzel, J.M., Despax, R., Jasmin, C., Levi, F., Musset, M., Machover, D., Ribaud, P. \& Misset, J.L. (1987) LH-RH agonist: breast and prostate cancer. In Hormonal Manipulation of Cancer:
Peptides, Growth Factors, and New (Anti) Steroidal Agents, pp. 353-356. Eds J. G. M. Klijn, R. Paridaens \& J. Foekens. Raven Press, New York.

Maynard, P.V. \& Nicholson, R.I. (1979) Effects of high doses of a series of new luteinizing hormone-releasing hormone analogues in intact female rats. $B r . J$. Cancer 39, $274-279$.

Mortel, R., Stayaswaroop, P.G., Schally, A.V., Hamilton, T. \& Ozols, R. (1986) Inhibitory effect of GnRH superagonist on the growth of human ovarian carcinoma NIH: OVCAR 3 in the nude mouse. Gyn Oncol. 23, 254 255, Abstr.

Niswender, G.D., Midgley, A.R., Jr, Monroe, S.E. \& Reichert, L.E., Jr (1968) Radioimmunoassay for rat luteinizing hormone with antiovine $\mathrm{LH}$ serum and ovine LH- ${ }^{131}$ I. Proc. Soc. exp. Biol. Med. 128, $807-811$.

Parmar, H., Lightman, S.L., Allen, L., Phillips, R.H., Edwards, L. \& Schally, A.V. (1985) Randomised controlled study of orchidectomy vs long-acting DTrp-6-LHRH microcapsules in advanced prostatic carcinoma. Lancet ii, 1201-1205.

Ramzy, I. (1983) Diseases of the uterine body, In Gynecologic and Obstetric Pathology, pp. 141-209. Ed. I. Ramzy. Appletonn Century-Crofts/Norwalk.

Redding, T.W. \& Schally, A.V. (1983) Inhibition of mammary tumor growth in rats and mice by administration of agonistic and antagonistic analogs of luteinizing hormone-releasing hormone. Proc. natn. Acad. Sci. USA 80, 1459-1462.

Redding, T.W., Schally, A.V., Tice, T.R. \& Meyers, W.E. (1984) Long-acting delivery system for peptides: inhibition of rat prostate tumors by controlled release of [D-Trp6] luteinizing hormone releasing hormone from injectable microcapsules. Proc. natn. Acad. Sci. USA 81, 5845-5848.

Roger, M., Duchier, J., Lahlou, N. \& Schally, A.V. (1985) Treatment of prostatic carcinoma with D-Trp-6-LHRH: plasma hormone levels after daily subcutaneous injections and periodic administration of delayedrelease preparation. The Prostate 7, 271-282.

Sandow, J., VonRechenberg, W., Jerzabek, G. \& Stoll, W. (1978) Pituitary gonadotropin inhibition by a highly active analog of luteinizing hormone-releasing hormone. Fert. Seril. 30, $205-209$.

Schally, A.V. \& Coy, D.H. (1983) Stimulatory and inhibitory analogs of LH-releasing hormone: Basic and clinical studies. In Role of Peptides and Proteins in Control of Reproduction, pp. 89-110. Eds S.M. McCann \& D. S. Dhindsa. Elsevier, New York.

Schally, A.V., Coy, D.H. \& Arimura, A. (1980) LH-RH agonists and antagonists. Int. J. Gynaecol. Obstet. 18, $318-324$. 
Schally, A.V., Kook, A.I., Monje, E., Redding, T.W. \& Paz-Bouza, J.I. (1986) Combination of a long-acting delivery system for luteinizing hormone-releasing hormone agonist with novantrone chemotherapy: increased efficacy in the rat prostate cancer model. Proc. natn. Acad. Sci. USA 83, 8764-8768.

Tolis, G., Mehta, A., Comaru-Schally, A.M. \& Schally, A.V. (1981) Suppression of androgen production by
D-tryptophan-6 LH-RH in man. J. clin. Invest. 68, 819 822.

Wang, N.G., Sudaram, K., Pavlou, S., Rivier, J., Vale, W. \& Bardin, C.W. (1983) Mice are insensitive to the antitesticular effects of luteinizing hormone-releasing hormone agonists. Endocrinology 112, 331-335.

Received 4 July 1988 